\title{
Det levende web og de døde
} links

\begin{abstract}
The article probes web referencing behavior among Danish researchers and students. Our study is concentrated on a selection of master's theses submitted in 2015 at the University of Copenhagen and an assortment of recent literary monographs focusing on contemporary literature. In the article we examine to what extent it is possible to follow each given web reference and we review the existing recommendations. Our study shows that current practices and ideals are inadequate, and we discuss a number of alternatives. It is our recommendation and conclusion that researchers and university students should strive to include web archives whenever they refer to internet resources. We furthermore argue that a web reference should consist of four specific elements in order to be both precise and persistent, and we introduce a concrete suggestion on how an up-to-date standard might be formulated.
\end{abstract}

Keywords: arkiveret web, henvisningsadfærd, citationspraksisser, stabile referencer

\section{Indledning}

Forskere og studerende gør i stigende grad brug af digitale ressourcer, herunder materiale, der alene kan tilgås via internettet. Internettet og de kulturelle fænomener, der kommer til udtryk heri, er genstand for $\varnothing$ get forskningsmæssig bevågenhed, og e-materialer supplerer og afløser i stigende grad fysiske materialer. Det giver anledning til at formulere nye forskningsspørgsmål og at besvare gamle problemstillinger på nye måder. Med de nye muligheder følger også en række udfordringer. Websider er forbundet på måder, der ikke ligner dem, vi kender fra andet materiale, mængden af tilgængeligt data overstiger, hvad vi hidtil har erfaring med, og der er endnu ikke udviklet en forskningsinfrastruktur, som i tilstrækkelig grad kan støtte op om den stigende brug af webressourcer (Brügger, 2012; Brügger \& Finnemann, 2013; Thomee et al., 2016).

Denne artikel sætter fokus på udfordringerne med at levere præcise og stabile henvisninger til webmateriale. Vi $\emptyset n$ sker dels at problematisere de eksisterende idealer og praksisser, og dels at fremsætte forslag til en ny best practice, der på lidt længere sigt kan danne grundlag for webreferencer i akademisk arbejde. Artiklen tager afsæt i referenceadfærden i to forskellige tekstkorpusser - et udvalg af specialeafhandlinger fra 2015 og litterære monografier fra 2011-16, der behandler dansk samtidslitteratur - og en undersøgelse af, i hvilket omfang de anvendte webressourcer kan identificeres på baggrund af de givne henvisninger. At begge undersøgelser 
fokuserer på output fra humaniora, skyldes først og fremmest, at den såkaldte digitale bølge har betydet, at disse fag nu i højere grad inddrager og studerer digitale udtryk (Terras et al., 2016). I kølvandet herpå er det derfor særligt relevant at undersøge Humanioras betingelser for at inddrage de nye materialetyper.

Det undersøgte materiale er naturligvis ikke dækkende for hele det humanistiske forskningsfelt, men vores stikprøver kan bruges til at identificere nogle faglige tendenser og problematikker. Vores målsætning er, at artiklen dermed kan bidrage til, at forskere og studerende kan levere bedre digitale referencer.

\section{Videnskabelige idealer og bibliografiske praksisser}

Akademisk arbejde står aldrig alene. Ifølge Den danske kodeks for integritet i forskning (2014) opfattes det som uredeligt, hvis forskere og universitetsstuderende ikke med "tilstrækkelige og præcise referencer" (s. 11) kan redegøre for, hvilket materiale deres undersøgelser bygger på, og hvordan de trækker på hidtidig forskning.

Der eksisterer ikke ét ideelt referencesystem, men snarere flere accepterede faglige modeller. Den præcise henvisning i og til akademisk arbejde fik sit egentlige gennembrud i midten af 1800 -tallet i forbindelse med udbredelsen af videnskabelige tidsskrifter og som følge af et behov for en højere grad af anerkendelse af forfatterskab og intellektuel ophavsret (Allen et al., 1994; Small, 2010; Price, 1963, s. 65). Referencer tjente dengang som nu - til at sikre, at forskningsresultater både kunne efterprøves og krediteres.

I de sidste årtier af 1800-tallet og første halvdel af 1900-tallet blev flere af de internationalt anerkendte standarder etableret, herunder Chicago- og Harvardsystemet samt APA der alle er blandt de mest anvendte i dag (Evans, 1992; Chernin, 1988). Disse systemer anvendes også af de fagfællebedømte tidsskrifter, som danske universitetsforskere hyppigst publicerer i. Akademisk Kvarter, som i 2015 tegnede sig for flest tidsskriftsartikler af forskere ansat ved humanistiske fakulteter i Danmark, pålægger bidragydere at anvende Chicagosystemets forfatter-dato-format. Nu nedlagte Kritik, der i 2015 stod for næstflest artikler, benyttede en version af samme system. Det dramaturgiske tidsskrift Peripeti, som samme år var det tredjemest populære tidsskrift blandt danske humanister, angiver referencer ved hjælp af den parentetiske Harvard-stil (Den Danske Forskningsdatabase). ${ }^{1}$

Valgfriheden er generelt større blandt studerende. Vores rundspørge blandt studieledere ved Københavns Universitets Humanistiske Fakultet pegede ikke på nogen systematiseret praksis. ${ }^{2}$ De fleste institutter underviser i referencehåndtering og studieteknik på første semester, men lader det som regel være op til den enkelte underviser, om der undervises i ét eller flere systemer. Den samme variation kommer til udtryk hos de mest anvendte forlag blandt danske universitetsforskere. Aarhus Universitetsforlag var i 2015 det forlag, der udgav flest monografier fra forskere ansat ved danske universiteter, efterfulgt af Samfundslitteratur og Museum Tusculanum samt Hans Reitzel på en delt tredjeplads. ${ }^{3}$ Aarhus Universitetsforlags Forfatterhåndbog (2014) anviser ikke ét bestemt system, når blot oplysningerne gør det muligt for læseren "at finde den kilde, der henvises til, og nøjagtig det sted, der citeres fra - og når blot, der er konsekvens i metode og opstilling" (s. 5). Som minimum beder forlaget dog om, at referencer indeholder dato, forfatter- og redaktørnavne, udgivelsens titel, evt. dato og nummer samt oplysninger om udgave (s. 4). Forlagene Samfundslitteratur og Hans Reitzel beder deres forfattere levere manuskripter, der følger en tillempet Harvard-stil (Ny forfattervejledning; personlig korrespondance med Dorte Steiness, 28/9 2016), mens Museum Tusculanum i deres Forfattervejledning (2016) understreger, at henvisninger kan laves på forskellig vis, blot det "aftales med redaktionen, så det gøres konsekvent" (s. 2).

Selvom ovenstående ikke peger på et konformt system blandt hverken universitetsundervisere eller forlæggere, råder der alligevel nogle grundlæggende principper. Disse er sammenfattet af Annette Skov, der i vejledningen Referér korrekt! angiver følgende minimumskrav til bibliografiske henvisninger:

- de skal rumme de bibliografiske elementer, der er tilstrækkelige til entydig identifikation og genfinding af dokumentet. 
- referencerne skal forekomme umiddelbart forståelige, dvs. at de enkelte elementer skal forekomme i en logisk rækkefølge og afspejle elementernes vigtighed som indgange i en genfindingsproces.

- de skal udarbejdes konsekvent! (Skov, 2014).

Har man brug for at henvise til materiale, som er hentet fra internettet, kommer man imidlertid til kort på de ovenstående parametre. De mest anvendte henvisningssystemer, Harvard og Chicago, beder ikke om oplysninger udover selve URL'en - dvs. den pågældende adresse for en ressource på internettet - og den dato, da denne sidst blev tilgået eller ændret (Preparing and Quoting; The Chicago Manual of Style, 2010). De unders $\varnothing$ gte danske forlag lægger op til en tilsvarende praksis. De anbefalede henvisninger har en så ringe detaljegrad, at man i realiteten ikke leverer det minimum af bibliografiske oplysninger, som forskere ifølge Den danske kodeks for integritet i forskning holdes ansvarlige for (Den danske kodeks, s. 11). Følger man de gængse henvisningssystemer, er det f.eks. ikke muligt at pege på specifikke elementer på en webside. Datoen for, hvornår en webside er bes $\varnothing$ gt, bidrager ikke til genfinding, og oplysningen har næsten ingen relevans i en tid, da mange websider opdateres flere gange i timen. Meget tyder altså på, at de systemer, der gennem årtier er blevet finjusteret i forhold til forskellige analoge kildetyper, ikke slår til, når det gælder webmateriale.

\section{Døde links - tilgang og begrebsafklaring}

Forskere har bekymret sig for websiders, domæners og individuelle webobjekters levedygtighed siden den folkelige udbredelse af internettet i 1990'erne (Benbow, 1998; Chankhunthod et al., 1995; Koehler, 1999). Relevansen og interessen i problemstillingen er steget med fremkomsten af det såkaldte web 2.0, som i modsætning til det tidlige internet er karakteriseret ved en $h ø j$ grad af brugerengagement og dynamik. Koehler (2002) beskriver resultaterne af et studie, der fulgte 361 URL'er over en fireårig periode. Konklusionen var, at omtrent $67 \%$ af de unders $\varnothing$ gte URL'er af den ene eller anden grund var utilgængelige efter fire år (Koehler, 2002). Studiet var baseret på tilfældigt udvalgte websider, men inspirerede til en række efterfølgende unders $\emptyset$ gelser, der søgte at klarlægge problemets omfang og karakter inden for specifikke fagfelter som historie (Russell \& Kane, 2008), informationsvidenskab (Dimitrova \& Bugeja, 2007; Goh \& Kin Ng, 2007; Kumar \& Kumar, 2012), jura (Liebler \& Liebert, 2012; Isfandyari-Moghaddam \& Saberi, 2011, Zittrain et al., 2014) og medicin (Aronsky et al, 2007; Dellavalle et al, 2003; Wren, 2008). Resultaterne varierer alt efter de typer links, der er blevet unders $\varnothing$ gt, hvilket tidsrum studiet favner, og hvilken målestok der anvendes, men konklusionerne er enslydende: Websider forandres med stigende hastighed, og URL'er er foruroligende ustabile.

Vores unders $\varnothing$ gelser henter inspiration fra ovenstående, men adskiller sig ved at fokusere på referenceadfærden hos danske forskere og studerende. Tidligere studier har bekræftet, at studerende i stigende grad gør brug af webressourcer (Davis \& Cohen, 2001), men der findes - så vidt vi er orienteret - ikke undersøgelser af, hvilke konsekvenser webreferencers ustabilitet har på opgaveniveau. Danske forskeres brug af webreferencer er heller ikke et område, der tidligere er blevet unders $\varnothing$ gt.

I vores to analyser kombinerer vi en kvalitativ og kvantitativ tilgang, der både giver indtryk af, hvordan studerende og forskere inddrager materiale fra internettet $i$ deres publikationer, og et snapshot af stabiliteten af de webreferencer, de giver. Vi har i to nyere tekstkorpusser -10 videnskabelige litterære monografier og 35 specialer fra Humaniora - udtaget samtlige referencer, der indeholder "www" og/eller "http" fra både brødtekst, fodnoter, litteraturlister og eventuelle bilag. Ved at følge disse URL'er har vi unders $\varnothing \mathrm{gt}$, om det enkelte link er $\mathrm{d} \varnothing \mathrm{dt}$, forstået på den måde at det ikke længere kan tilgås på det levende net. En webside kan af forskellige grunde være nede $\mathrm{i}$ en midlertidig periode, hvorfor vi har fors $\emptyset \mathrm{gt}$ at tilgå siderne to gange med fire ugers mellemrum. Begge fors $\varnothing \mathrm{g}$ gav dog samme resultat. Alle URL'er, der ikke responderede, blev desuden afprøvet i forskellige browsere for at sikre, at dette ikke var årsagen til, at en bestemt webside var utilgængelig.

\section{Referenceadfærd blandt specialestuderende}

For at få en forståelse af, hvordan studerende i praksis inddrager internetmateriale i deres opgaveskrivning, 
undersøger vi her et udvalg af de danske specialer, der er indlemmet i specialedatabasen DISKURS. DISKURSprojektet blev påbegyndt i 2012 af Københavns Universitetsbibliotek, og da vi 29. februar 2016 påbegyndte vores unders $\varnothing$ gelse, indeholdt databasen knap 3.500 specialer forfattet af kandidatstuderende ved Københavns Universitet. Det svarer sammenlagt til knap 1/5 af alle specialer, der blev indleveret i perioden 2012-16.

Specialerne er indlemmet på frivillig basis under en Creative Commons-licens af typen by-nc-nd (Creative Commons). Materialet er tilgængeligt via en brugergrænseflade, hvor specialets forskellige dele (brødtekst, bilag m.m.) foreligger som separate PDF'er. DISKURS giver dermed adgang til et forholdsvist stort og repræsentativt materiale, der kan give et unikt indblik i, hvordan specialestuderende anvender ressourcer fra internettet.

I denne artikel fokuserer vi alene på specialer, der er indleveret ved fag under det Humanistiske Fakultet i den senest mulige fuldendte periode, nemlig 2015. Fra dette år rummer DISKURS i alt 35 specialer fordelt på institutterne ENGEROM (19), INSS (8), TORS (3), MEF (2), IKK (2) og SAXO (1). Det svarer til 3,3\% af den samlede mængde beståede specialer, der i 2015 blev indleveret ved de samme institutter. ${ }^{4}$ Diskrepansen institutterne imellem illustrerer det forhold, at kun nogle fag har opfordret studerende til at uploade deres speciale i DISKURS (DISKURS FAQ). Det Informationsvidenskabelige Akademi (IVA) har f.eks. etableret en selvstændig database over de studenteropgaver, der er indleveret på instituttet (IVA Studenterprojekter). ${ }^{5}$

Specialerne spænder over en bred vifte af empiriske emner - fra Shakespeare til sociale medier i tyskundervisningen - der ikke giver anledning til at tro, at mængden af webreferencer skulle være overrepræsenteret i de opgaver, vi her unders $\varnothing$ ger. De 35 unders $\varnothing$ gte specialer rummede sammenlagt 899 referencer, der indeholdt "http" og/eller "www". ${ }^{6}$ Disse optrådte i brødtekster, fodnoter, bilag og litteraturlister. I gennemsnit indeholdt hvert speciale 26,4 webreferencer, men tallene dækker dog over relativt stor varians. Et speciale skilte sig således ud ved ikke at indeholde én eneste henvisning til materiale fra internettet, mens tre andre alle indeholdt over 80 henvisninger.

I en unders $\varnothing$ gelse af, hvor stor en andel links, det i skrivende stund er muligt at følge, er det nødvendigt at tage højde for, at de studerende har forskellige praksisser: Nogle angiver alene webreferencer i enten fodnote eller litteraturliste, andre begge steder således at samme reference altid optræder mindst to gange i specialet. Det kan betyde, at specialer, der lever op til den generelle anbefaling om, at lade alle benyttede værker fremgå af litteraturlisten, vil have en markant højere andel døde links. For at undgå denne skævvridning foretager vi alene vores måling på unikke webreferencer. Den specifikke webreference tæller altså kun én gang, uanset om forfatteren flere gange refererer til samme URL. Dermed følger vi det informationsvidenskabelige skel mellem henholdsvis citationer og referencer (Bruhns, 2010, s. 17-18 og 169ff).

Flere forskere sondrer mellem link rot og reference rot (Sanderson et al., 2011; Zittrain et al, 2014). Link rot betegner situationen, hvor et link ikke længere virker, mens reference rot dækker over, at et webelements indhold - f.eks. en tekstblok - er ændret, siden referencen blev givet. Reference rot er et komplekst, men givetvis meget udbredt fænomen, som vi ikke tjekker for i vores unders $\varnothing$ gelse af specialerne. Vi har alene unders $\emptyset \mathrm{gt}$, om en webside viser et indhold, der med al tydelighed er utilsigtet - f.eks. en tidligere onlinekildesamling, der er erstattet af en webshop - eller om en given URL resulterer i et dødt link i form af en webside, som enten ikke kan findes (en såkaldt "404-fejl") eller ikke kan vises på grund af en blokering. 


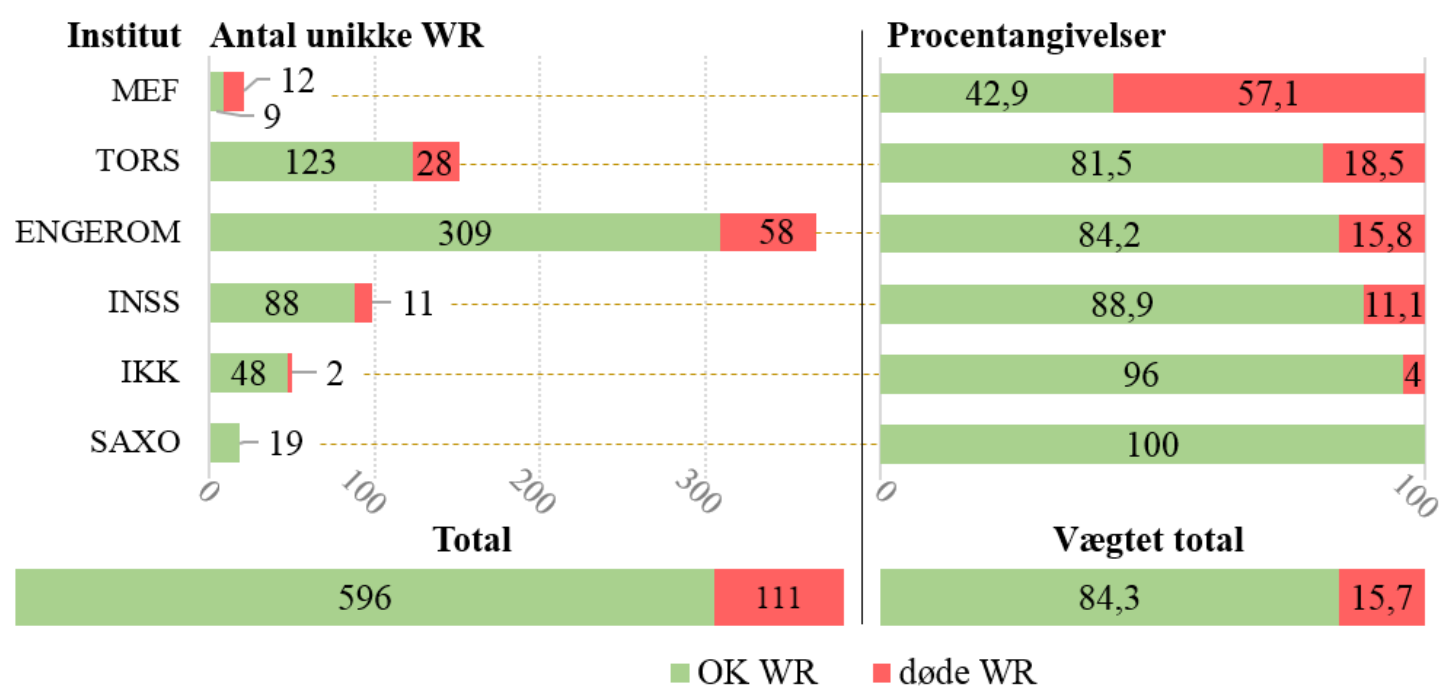

Figur 1: Unikke webreferencer (WR) i specialer, fordelt på institut. Kilde: https://diskurs.kb.dk, Humanistiske specialer indleveret på KU i 2015

Døde links påvirkede $3 / 4$ af de unders $\varnothing$ gte specialer. Ud af sammenlagt 707 unikke webreferencer resulterede 111 i en fejlmeddelelse om, at indholdet eller serveren ikke blev fundet (figur 1). Det betyder, at 15,7\% af alle henvisninger til webmateriale ikke kan følges af læseren, og at den information, de peger på, ikke kan tjekkes. Der er dog forholdsvist store udsving. I nogle af specialerne fungerede samtlige links, mens der i andre tilfælde var tale om, at cirka hvert fjerde link ikke kunne følges. Selvom specialer først og fremmest er meriteringsprodukter, er de stadig en del af den humanistiske videnproduktion, hvorfor det er utilfredsstillende, at en betragtelig mængde referencer er utilgængelige efter relativt kort tid.

Materialet er for lille til, at man generelt kan sige noget om, hvorvidt og hvorfor nogle institutter har en højere andel døde links. Det er imidlertid påfaldende, at der er så mange fejlbehæftede webreferencer blandt specialer indleveret på MEF, og det er nærliggende at forklare dette med, at fagene på instituttet analyserer nyere kommunikationskanaler, bl.a. sociale medier, der er meget dynamiske og derfor i særlig grad påvirkes af linkdød.

En fejlprocent på 16\% skiller sig ikke væsentligt ud, hvis man sammenligner med henvisninger til øvrige materialetyper. Benning og Speer (1993) fandt både mindre og mere alvorlige fejl i mellem 15 og $35 \%$ generelle henvisninger i tre udvalgte informationsvidenskabelige tidsskrifter udgivet i 1989. Et større studie fra 1992, der unders $\varnothing$ gte artikler bragt i ti anerkendte informationsvidenskabelige tidsskrifter, fandt at $30 \%$ af henvisningerne var fejlbehæftede. Af disse fejl var over halvdelen så alvorlige, at læseren ikke havde mulighed for at finde det værk, der blev refereret til (Pope, 1992). Den mængde fejl, vi har identificeret for webreferencernes vedkommende, er imidlertid opsigtsvækkende set i lyset af, at mange af henvisningerne blev tjekket mindre end et år efter, at specialet blev indleveret. Diakrone linkanalyser har påvist, at dødshyppigheden stiger markant med et links alder (Dellavalle et al, 2003, s. 787; Russell \& Kane, 2008). Ved at gennemgå alle URL-henvisninger i fem prominente journalistiske og informationsvidenskabelige tidsskrifter fra perioden 2000-03 kunne Dimitrova \& Bugeja (2007) fastslå, at der for den undersøgte fireårsperiode var en gennemsnitlig halveringstid - den tid, det tager, før 50\% af et givent antal links ikke længere virker - på 3,17 år. Der er derfor god grund til at formode, at antallet af $d \varnothing$ de links i de undersøgte specialer vil stige yderligere, og netop i denne henseende skiller webreferencer sig ud. Mens henvisninger til analoge materialetyper er stabile - med og uden fejl - vil andelen af fejlbehæftede webreferencer i det enkelte værk med stor sandsynlighed stige med tiden.

Delunders $\varnothing$ gelsen identificerer ikke alene andelen af døde links i de unders $\varnothing$ gte specialer, men kan også tegne et billede af, hvordan studerende benytter webressourcer, og hvilken indflydelse dette har på stabiliteten af deres henvisninger. Størstedelen af de webressourcer, de studerende henviste til, indgik som primær- eller 
sekundærlitteratur i form af digitaliserede kildesamlinger og elektroniske tidsskriftsartikler. Opslag i digital referencelitteratur - f.eks. KVINFOs online-udgave af Dansk Kvindebiografisk Leksikon, Gyldendals Den Store Danske og Oxforddictionaries.com - var næstmest forekommende. Specialeskriverne henviste også ofte til online-medieklip, bl.a. YouTube-videoer og radioudsendelser. Især for de digitaliserede kildesamlinger og de elektroniske tidsskriftsartikler var der en høj grad af stabilitet. En stor del af de døde links, vi fandt i specialerne, var resultatet af, at firmaer eller offentlige instanser rykkede indhold til nye placeringer, eller at indhold bevidst var taget af nettet. Det sidste gælder typisk for de private og offentlige mediehuse, som kun tilbyder onlineadgang til deres materiale $i$ en afgrænset tidsperiode, samt når YouTube-brugere fjerner indhold fra websitet.

Som nævnt anbefales det i de fleste referencestandarder, at en henvisning til en internetside dannes af en URL og datoen for sidste opdatering eller besøg. Men da man på hjemmesider i dag sjældent finder informationer om en given websides seneste opdatering, er denne anbefaling uanvendelig, og ingen af de undersøgte specialer havde indføjet denne type information. Af de i alt 33 specialer, der henviste til specifikke URL'er, havde syv specialer ikke dato knyttet til ét eneste link i litteraturliste eller fodnoter. Et tilsvarende antal specialer (21\%) angav en dato for hvert link, der henvistes til. De fleste specialeskrivere, 58\%, angav datoen for, hvornår de havde "besøgt", "hentet", "lokaliseret", "set" eller "tilgået" visse, men ikke alle, websider.

Man kan altså hverken tale om konsekvens i det samlede undersøgte korpus eller inden for det enkelte speciale. Som nævnt ovenfor gælder det desuden, at der i brødteksten eller i fodnoten ofte bliver henvist til en webressource, som ikke optræder på litteraturlisten. Tilsvarende har flere henvisninger ikke tilstrækkelig præcision. Flere henvisninger leder f.eks. til forsiden af en blog eller til en google- eller bibliotekssøgning, der ikke giver læseren mulighed for at vurdere, hvad der henvises til. Specialerne illustrerer altså, at de studerende ikke altid er konsistente eller præcise, når de henviser til webressourcer. Undersøgelsen viser imidlertid også, at selv når studerende følger den anbefalede praksis, kan der være problemer med at tilgå de ressourcer, der refereres til.

\section{Referenceadfærd blandt forfattere til litterære monografier}

Det litterære felt har på lige fod med andre dele af kulturen undergået en markant transformation som følge af digitaliseringen og internettet. Både de trykte bøger samt den litterære kritik i aviser, tidsskrifter og monografier er blevet suppleret af en række nye kanaler, der tilsammen giver et langt mere komplekst og uoverskueligt billede. Internettet er blevet en del af den litterære fødekæde, da nettet nu både fungerer som produktions-, distributions- og receptionskanal for litterære tekster og kritik. Især receptionskanalen er central, idet først blogs og senere de sociale medier har resulteret i en decentralisering af den offentlige litterære debat, hvor især artikler recirkuleres, debatteres, likes osv. Med andre ord: den netværkede læseraktivering.

Materialet til denne del af vores undersøgelse består af væsentlige litterære monografier, hvor emnet helt eller delvist er dansk samtidslitteratur, ${ }^{7}$ skrevet af danske forskere og udgivet på universitetsforlag eller forlag, som opererer med tilsvarende akademiske krav, i årene 2011-16. ${ }^{8}$ Det er altså værker, der skal leve op til almene videnskabelige krav om præcise referencer, herunder anvendelsen af litteraturliste og fodnoteapparat. ${ }^{9}$ । kronologisk rækkefølge drejer det sig om:

- $\quad$ Anne-Marie Mai, Hvor litteraturen finder sted (2011)

- Martin Gregersen og Tobias Skiveren, Det åbne redskabsskur: hovedstrømninger i det nye årtusindes danske forfatterskolelitteratur (2013)

- Martin Glaz Serup, Relationel poesi (2013)

- Jon Helt Haarder, Performativ biografisme: en hovedstrømning i det senmodernes skandinaviske litteratur (2014)

- Peter Stein Larsen, Poesiens ekspansion: om nordisk samtidsdigtning (2015)

- Marianne Stidsen, Den ny mimesis. virkelighedstolkningen i dansk og nordisk litteratur efter Anden Verdenskrig (2015) 
- $\quad$ Erik Svendsen, Kampe om virkeligheden: tendenser i dansk prosa 1990-2010 (2015)

- Anne-Marie Mai, Galleri 66: en historie om nyere dansk litteratur (2016)

- Louise Mønster, Ny nordisk: lyrik i det 21. århundrede (2016)

- Tue Andersen Nexø, Vidnesbyrd fra velfærdsstaten: den sociale vending i ny dansk litteratur (2016)

Anvendelsen af webreferencer i disse værker fordeler sig over et bredt spektrum (figur 2).

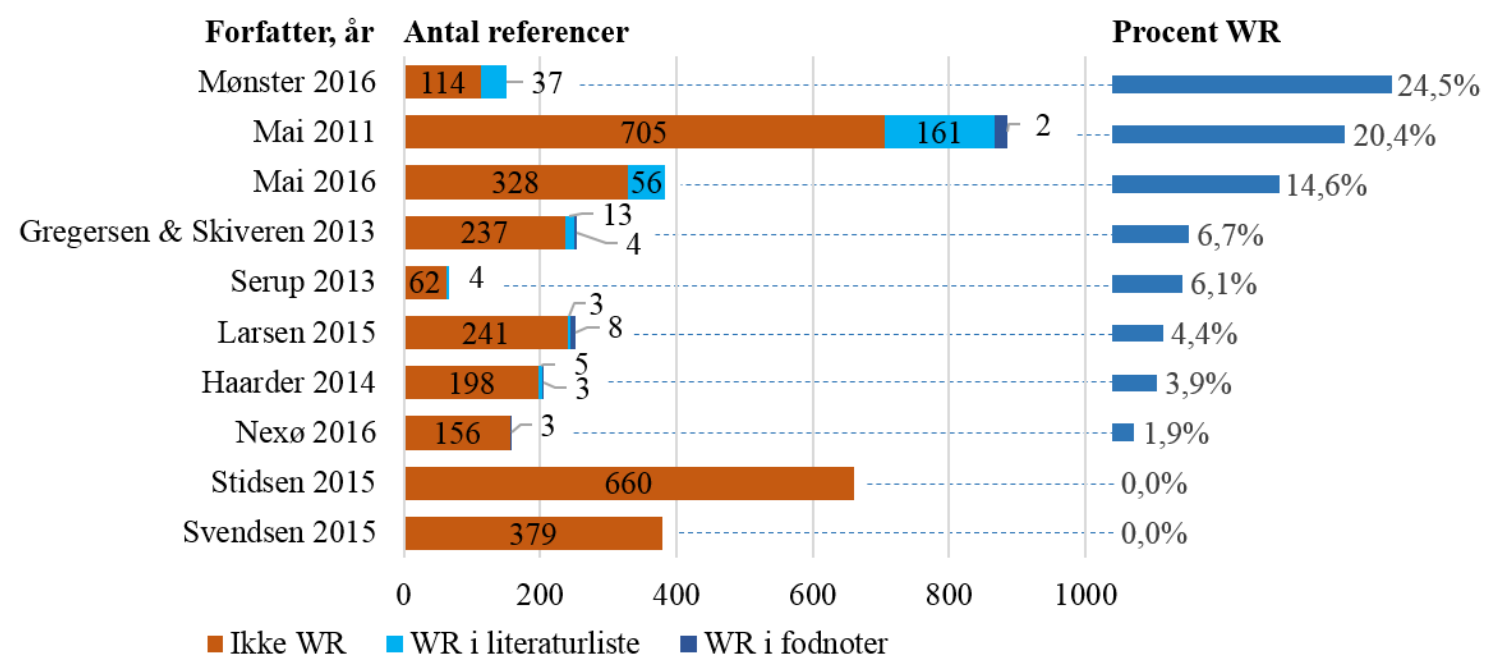

Figur 2: Referencer, herunder webreferencer, i udvalgte danske litterære monografier, 2011-16

I de ti unders $\varnothing$ gte værker finder man i alt 3.397 litteraturreferencer, heraf 634 unikke webreferencer, dvs. knap 19\%. Dette tal dækker over et stort spænd. Blandt de akademiske udgivelser, hvori webreferencer spiller en substantiel rolle, finder man Mai (2011) og Mai (2016) med hhv. 20,4 og 14,5\% webreferencer, kun overgået af Mønster (2016) med 24,5\%. Sidstnævnte værk har da også et samtidslitterært sigte, hvor blogs, websider m.m. spiller en central rolle, og webreferencerne favner både primært og sekundært materiale. I den anden ende af spektret spiller webreferencer en meget lille eller slet ingen rolle: Tue Andersen Nexøs samtidslitteratursdiagnose Vidnesbyrd fra velfærdsstaten (2016) har beskedne tre webreferencer (skjult i fodnoter), og Marianne Stidsens to-binds disputats indeholder hele 660 litteraturreferencer, men ikke én eneste webreference. Samlet set kan man således ikke tale om en klar tendens i anvendelsen af webreferencer i monografierne, og webreferencernes placering er heller ikke entydig: I nogle af værkerne står webreferencerne i litteraturlisten, i andre kun i fodnoterne, og en tredje variant er at have nogle webreferencer på litteraturlisten og andre kun i fodnoterne.

Tallene indikerer, at en betydelig del af den litteraturhistoriske forskning stadig har fokus på de trykte litterære værker, og at den væsentligste forskning inden for området stadigvæk bliver bragt i trykte medier. Man kan dog ikke udelukke at webreferencers potentielle ustabilitet (angsten for linkdød) spiller en rolle: Monografier tiltænkes ofte en længere levetid end f.eks. artikler, og allerede ved et værks udgivelse vil der være gået kortere eller længere tid, siden webreferencen blev anført. Ingen af de unders $\varnothing$ gte litterære monografier angiver en sidst-tilgået-dato med undtagelse af Mai (2016), hvor man kan konstatere, at sidst-tilgået-datoerne befinder sig et sted mellem en og ni måneder fra udgivelsestidspunktet. I modsætning til specialerne har vi ikke foretaget et systematisk tjek af alle webreferencerne i monografierne. Det er imidlertid sigende, at unders $\varnothing$ gelsesmaterialets senest udgivne værk - Tue Andersen Nexøs Vidnesbyrd fra velfærdsstaten, som vi gennemgik i form af et anmeldereksemplar - indeholdt 2/3 døde links. Inden bogen overhovedet var udkommet!

Mai (2011) er det ældste værk, der indgår i undersøgelsen og i vid udstrækning anvender webreferencer, hvorfor det i det følgende vil være genstand for en nærmere undersøgelse. I forlængelse af moderne stedsteori har 
litteraturprofessor Anne-Marie Mai i trebindsværket Hvor litteraturen finder sted (2011) skrevet en ny litteraturhistorie med udgangspunkt i de steder, der har været omdrejningspunkt for skønlitteraturen, bl.a. herregårdene, hoffet, akademierne, salonen, præstegården, bladhuset, metropolen - og internettet. Tredje bind afsluttes med et kapitel om internettets litteratursteder, der i modsætning til de øvrige er et fundamentalt andet og ustabilt sted, hvilket Mais bog kan tjene til at demonstrere. Mai er vidt omkring, og i teksten samt fodnoter indgår i alt 181 referencer til "steder" på internettet: danske litteraturinstitutioner (litteraturbanker, forfatterarkiver m.m.), udenlandske litteraturinstitutioner, danske websider om litteratur, danske forfatteres hjemmesider og blogs. Hertil kommer dansk og udenlandsk skønlitteratur, enten født digitalt eller digitaliseret, i Danmark og udlandet. Endelig refererer Mai til danske og udenlandske artikler, der er publiceret på nettet.

For at anskueliggøre læserens muligheder for at tilgå det webmateriale, der refereres til, kan man anvende trafiklysets tre farver, hvor "grøn" betegner links, der virker og efter alt at dømme refererer til det tilsigtede indhold. "Gul" er mere kritisk og omfatter referencer, hvori der enten linkes til en generel side med angivelse af hvilke oplysninger, der skal søges frem, eller et "redirect" til den overordnede hjemmeside, hvorpå man (måske) kan finde det ønskede indhold. Endelig anvendes farven "Rød", når der er tale om et dødt link eller en anden websides overtagelse af indholdet.

Fem år efter at Mai (2011) udkom, er 34,3\% (62) af de anvendte links røde. Enten resulterer de i en fejlmelding, eller også bliver man sendt videre til en webside - typisk af kommerciel karakter - der intet har at gøre med det tilsigtede. I forhold til Koehler (2002), ifølge hvilken 67\% af de anvendte links var døde efter fire år, er 34,3\% stadigvæk et højt tal, ikke mindst fordi en betydelig del af Mais webreferencer henviser til hovedsider (f.eks. forfattersider som mettemoestrup.dk), der, trods nok så omfattende omlægninger, har høje overlevelsesrater.

21\% (38) er gule: Man kommer ind på en webside, som man har grund til at tro, er den rigtige, hvor man så kan lede efter (og relativt let finde) det refererede indhold. For næsten halvdelen af forfatterens webreferencer, $44,7 \%$, fungerer linket, og vi kommer direkte til et indhold, der matcher det beskrevne (grønt). Men her gælder dog stadig et principielt og konkret problem, nemlig at vi ikke kan være sikre på, at det er præcist den side, som Mai rent faktisk hentyder til, fordi den i mellemtiden kan have forandret sig i større eller mindre grad (jf. den tidligere nævnte tendens til reference rot). De mest stabile links er faktisk visse af de gule, hvor der henvises til en hovedside (f.eks. emmagad.dk) med specificering af, hvilken konkret artikel Mai refererer til. Hvor det konkrete indhold via en længere URL, der henviser til undersider, er i fare for at forsvinde, når websiden bliver lagt om, så kan en kortere URL eksistere længere. Det tyder på, at der for webreferencernes vedkommende opstår et paradoksalt modsætningsforhold mellem præcision og persistens. ${ }^{10}$

\section{Muligheder}

Vores undersøgelser peger altså på, at hverken studerende eller forskere leverer stabile eller præcise referencer, når de henviser til det levende web. Det gælder vel at mærke også i de tilfælde, hvor skribenterne faktisk følger de standarder, som de gængse referencesystemer opererer med. Ikke desto mindre er der i takt med internettets udbredelse blevet udviklet en række Iøsningsforslag som alternativ til den gængse URL + dato-reference. De eksisterende løsningsmuligheder kan grupperes i tre hovedkategorier - 1) eksisterende "persistent identifiers"tiltag, 2) citationstjenester og 3) webarkivsreferencer. De vil i det følgende blive diskuteret med fokus på den dokumenterede praksis blandt danske forskere og studerende, samt i hvor høj grad de imødekommer danske standarder for god videnskabelig skik, som den skitseres af (Skov, 2004) og Den danske kodeks for integritet $i$ forskning (2014).

De første "persistent identifiers" (PID) blev i midten af 1990'erne introduceret og udbredt i forskellige udgaver under forkortelser som ARK (Archival Resource Keys) og PURL (Persistent Uniform Resource Locators) (Price, 2012). Fælles for initiativerne står, at de giver den enkelte bruger mulighed for at registrere digitalt materiale, således at der - på linje med de ældre ISBN- og ISSN-numre - kan genereres entydige referencer hertil. Et udbredt eksempel er Crossrefs DOI (Digital Object-Identifier), der især bliver anvendt til at pege entydigt på elektroniske tidsskriftsartikler og bøger. I en national sammenhæng har en række danske institutioner udviklet en dansk 
variant af DOI'en i form af den såkaldte danPID (infopid.dk).

En PID's fordel består først og fremmest i, at lokalisering og navngivning holdes adskilte og uafhængige. Hvis et digitalt objekt flyttes, skal den nye placering således kun ændres ét sted. Derved etableres en mere vedvarende reference, der ikke er nær så sårbar som en URL, hvis funktionalitet afhænger af, at overensstemmelsen mellem navn og lokalisering består.

Eksisterende PID'er kan dog ikke til fulde sikre, at vi lever op til princippet om tilstrækkelige og præcise referencer. De forskellige tjenester giver ikke mulighed for at arkivere webmateriale, og det er alene op til materialeejeren at stå for registrering. Det betyder i praksis, at en stor mængde relevant kildemateriale ikke er forsynet med en PID. Det gælder således også for en del af det materiale - personlige websider, forfatterblogs osv. - danske forskere og studerende benytter. Endeligt er det væsentligt at holde in mente, at PID'ens holdbarhed afhænger af, at tjenesten opretholdes over tid, og at materialeejerne vedligeholder indholdet, så det kan tilgås uændret i fremtiden.

Såkaldte citationstjenester er et andet løsningsforslag, der er blevet bragt i spil i forbindelse med de problemer, som knytter sig til den nuværende praksis for webreferencer. I løbet af de sidste ti år er en stadig bredere vifte af kommercielle og nonprofit-aktører begyndt at tilbyde mulighed for både at arkivere snapshots af websider og danne referencer til dem. ${ }^{11}$ Disse tjenester sikrer altså - så længe de eksisterer og benyttes - at man kan henvise til f.eks. et wikipediaopslag uden i den sammenhæng at frygte linkdød eller ændringer på websiden. Visse referencehåndteringsprogrammer, f.eks. Zotero, har med tiden tilføjet samme funktionalitet, og en række programmer er blevet udviklet med henblik på at arkivere specifikke sider og on-screen action. ${ }^{12}$ Ligesom for PIDtjenesternes vedkommende er det dog en ulempe, at referencernes levetid afhænger af serviceudbyderen. Vi har allerede set eksempler på, at tjenester er gået ned. Det gælder bl.a. mummify.it, der blev søsat i 2013, men kuldsejlede allerede året efter (Sompel \& Davis, 2015, s. 58; Zierau et al., 2016, s. 247). Desuden skal man være opmærksom på, at de færreste citationstjenester giver brugeren mulighed for tilgængeliggøre data. Disse tjenester kan altså ikke sikre, at forskningsresultater, der bygger på webressourcer, kan efterprøves og reproduceres.

Løbende arkivering, bevaring og tilgængeliggørelse af webmateriale er en langt mere kompleks opgave, der kræver planlægning og monitorering og som i dag bedst håndteres af dedikerede webarkiver. ${ }^{13}$ Disse arkiver giver de bedste muligheder for at levere stabile webreferencer. Arkiveringen sker som led i bevaring af kulturarv, og i mange tilfælde er det som led i de nationale pligtafleveringsbestemmelser, hvortil der er afsat offentlige midler. Selvom det ikke giver garanti for evigt liv, overgår webarkivernes overlevelseschancer uden tvivl projekter af mere kommerciel og nicheorienteret karakter.

Udfordringen for brugere, der ønsker at anvende webarkiver i deres forskning er, at mange lande ikke giver umiddelbar adgang, fordi materialet kan indeholde personfølsomme oplysninger (Moesgaard \& Weimann, 2014, s. 4). Ønsker man som læser at forfølge en reference i et webarkiv, må man derfor ofte søge om adgang. Men principielt er adgangskravene til det danske Netarkivet ikke meget anderledes end de, der opstilles for interesserede, som $\varnothing$ nsker at se kildemateriale i andre nationale arkiver, f.eks. Rigsarkivet.

Hvis man ikke kan finde en given webside i et eller flere webarkiver, ${ }^{14}$ så kan man i visse tilfælde bede om at få websiden arkiveret. Den mulighed eksisterer f.eks. i Internet Archive, der ved søgninger automatisk spørger, om man ønsker at gemme en side, såfremt den ikke allerede findes i arkivet. Tilsvarende har både danske Netarkivet og UK Web Archive en onlineformular, der giver brugere mulighed for at indmelde domæner, som de ønsker gemt for eftertiden. De nævnte webarkiver arkiverer dog kun domæner, som bliver opfattet som henholdsvis danske og britiske.

\section{Anbefalinger}

Webarkiver - og især nationale webarkiver - er altså at foretrække, hvis man ønsker at undgå problematikken 
med døde links. Selvom webarkiver har nogle udfordringer, så bliver der løbende taget initiativer til at gøre materialet mere tilgængeligt for forskere og studerende. ${ }^{15}$

For at gøre det muligt at referere til arkiveret webmateriale, er det imidlertid nødvendigt at etablere en teknologiuafhængig reference og dermed komme udenom den forældede URL+dato-standard. På baggrund af vores undersøgelser af praksis inden for brug af webreferencer, har vi identificeret fire ingredienser, som er påkrævede for at kunne lave en præcis, persistent og transparent reference til en webressource i et vilkårligt webarkiv:

1) Webarkiv er en entydig angivelse af webarkivet (f.eks. Netarkivet eller Internet Archive). Så længe der ikke eksisterer et dedikeret register for adressering af webarkiver, opnår man den mest præcise angivelse ved at bruge webarkivets domænenavn, f.eks. netarkivet.dk.

2) Arkiveringstidspunkt er det tidspunkt, som webarkivet har registreret i forbindelse med, at webressourcen blev hentet fra det levende web. Dette bør angives i UTC (Coordinated Universal Time) for at undgå uklarheder, idet en webressource f.eks. kan være placeret på en maskine i én tidszone, mens selve arkivet befinder sig i en anden.

3) Arkiveret URL er webressourcens placering, da den blev arkiveret (bliver til et "navn", en såkaldt URI, når den refereres i et webarkiv, idet der ikke længere er tale om en lokation på webbet). ${ }^{16}$

4) Omfattet indhold angiver den del af webressourcen, som er omfattet af referencen. Dette er særligt vigtigt for webressourcer, fordi de kan omfatte flere webelementer. En webside er opbygget af forskellige elementer, så det er vigtigt, at man har mulighed for at pege præcist på de enkelte billeder, tekstblokke mv.

Med ovenstående fire ingredienser kan en webreference skrives i tekstform som følger:

Webarkiv: archive.org, arkiveringstidspunkt: 2016-06-28 09:13:34 UTC, arkiveret URL:

http://ntik.dk/forfattervejledning.htm, omfattet indhold: webside.

Vores forslag omfatter også en såkaldt PWID URI, som på sigt kan bruges til at åbne en arkivressource direkte i en browser (Zierau et al., 2016). Denne mulighed ligger uden for de krav, som god videnskabelig praksis omfatter, men gør, at brugerne kan tilgå webarkivmateriale på samme vis, som de er vant til: med et klik. Den ovenfor anførte reference ville som PWID URI se ud, som det fremgår af figur 3.

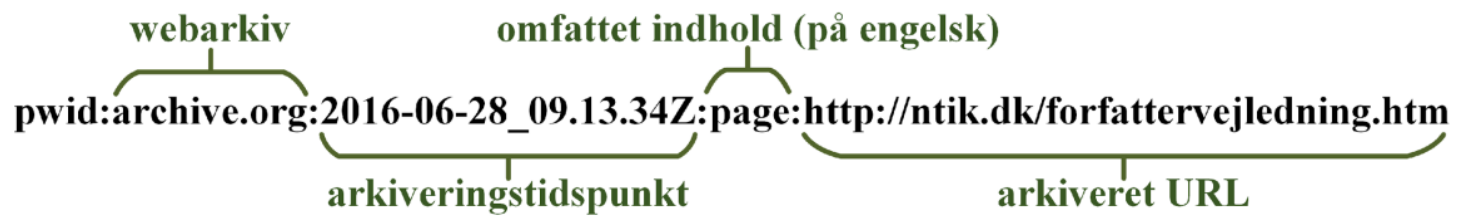

Figur 3: PWID URI med forklarende tekst til deleelementer

Et webarkiv kombineret med en reference, der indeholder disse fire ingredienser, giver altså de bedste betingelser for at pege præcist, uden at det sker på bekostning af muligheden for at genfinde ressourcen. Med tiden vil en PWID tillige kunne forenkle tilgængeliggørelse af kildematerialet. For at illustrere, hvorledes sådanne referencer konkret kan finde anvendelse, har vi som supplement til forfattervejledningen i denne artikel fulgt vores egne anbefalinger. For referencer til lukkede webarkiver har vi brugt tekstformen, mens vi for åbne og tilgængelige webarkiver har anvendt URI-formen.

\section{Det levende web og de døde links - konklusioner}

I en tid, da forskere i stigende grad finder deres materiale online, er der behov for, at vi kan henvise til webressourcer på en måde, der lever op til de eksisterende principper for god videnskabelig praksis. I artiklen har vi dokumenteret, at de en stor del af de undersøgte referencer ikke indeholder tilstrækkelige informationer 
til "entydig identifikation og genfinding" (Skov, 2014). Vores undersøgelse peger desuden på, at både forskere og studerende leverer upræcise og ustabile webreferencer, selv når de følger anerkendte referencesystemer og almene anbefalinger.

Diakrone studier har vist, at der er nær sammenhæng mellem en webreferences alder og risikoen for linkdød. De nuværende problemer med d $\varnothing$ de links i de unders $\varnothing$ gte udgivelser vil derfor kun blive st $\varnothing$ rre over tid. Dette er en særegen problemstilling, der ikke gør sig gældende for referencer til analoge materialetyper. Gennemgangen af de konkrete webreferencer illustrerer endvidere den paradoksale pointe, at præcision og persistens ofte er modstridende: På det levende web vil en overordnet webside som f.eks. dr.dk eller kb.dk ofte have en længere levetid end undersider, der hyppigere forsvinder eller skifter indhold. Referencer, der indeholder et link til en underside, må derfor forventes at have en relativt højere $\mathrm{d} \varnothing \mathrm{d}$ srisiko.

De dokumenterede problemer $\mathrm{i}$ forhold til præcision og persistens bør danne grundlag for en kritik af den anbefalede og meget anvendte URL+dato-standard. I artiklen identificerede og diskuterede vi tre alternative løsningsmodeller, der trods ulemper i højere grad ville hjælpe med at sikre, at webreferencer lever op til god videnskabelig praksis. Det er vores konklusion, at webarkiver giver de bedste muligheder for at levere ordentlige referencer til webressourcer, men også at der $b \varnothing r$ etableres en ny referencestandard, før webarkivernes potentiale til fulde kan udnyttes. Vores unders $\varnothing$ gelse af mere end 1.300 webreferencer fra specialestuderende og forskere munder derfor ud i et bud på en opdateret referencestandard, der i højere grad lever op til god videnskabelig praksis.

\section{Referencer}

Allen, B., Qin, J., \& Lancaster, F. W. (1994). Persuasive communities: A longitudinal analysis of references in the Philosophical Transactions of the Royal Society, 1665-1990. Social Studies of Science, 24(2), 279-310.

Aronsky, D., Madani, S., Carnevale, R. J., Duda, S., \& Feyder, M. T. (2007). The Prevalence and Inaccessibility of Internet References in the Biomedical Literature at the Time of Publication. Journal of the American Medical Informatics Association, 14(2), 232-34. doi:10.1197/jamia.M2243

Benbow, S. M. P. (1998). File Not Found: The Problems of Changing Urls for the World Wide Web. Internet Research, 8(3), 247-50. doi:10.1108/10662249810217867

Benning, S. P., \& Speer, S. C. (1993). Incorrect Citations: A Comparison of Library Literature with Medical Literature. Bulletin of the Medical Library Association, 81(1), 56-58.

Bruhns, Svend. (2010). Citationsindexering. Klarup: Bibliografica.

Brügger, N. (2012) L'historiographie de sites Web: Quelques enjeux fondamentaux. Temps Medias Temps des Medias, 18(1), 159-69.

Brügger, N., \& Finnemann, N. O. (2013). The Web and Digital Humanities: Theoretical and Methodological Concerns. Journal of Broadcasting \& Electronic Media, 57(1), 66-80. doi:10.1080/08838151.2012.761699

Chankhunthod, A., Danzig, P. B., Neerdaels, C., Schwartz, M. F., \& Worrell, K. J. (1995). A Hierarchical Internet Object Cache; CU-CS-766-9. Computer Science Technical Reports. Paper 720.

Chernin, E. (1988). The "Harvard system": a mystery dispelled. BMJ: British Medical Journal, 297(6655), 106263.

Creative Commons - Kreditering-IkkeKommerciel-IngenBearbejdelse 2.5 Danmark - CC BY-NC-ND 2.5 DK. Lokaliseret på https://creativecommons.org/licenses/by-nc-nd/2.5/dk/, webarkivreference: pwid:archive.org:2016-12-11 22.10.56Z:page:https://creativecommons.org/ licenses/by-nc-nd/2.5/dk/ 
Den Danske Forskningsdatabase. Lokaliseret på http://www.forskningsdatabasen.dk/, webarkiv:netarkivet.dk, arkiveringstidspunkt: 2017-03-09 18:01:50 UTC, arkiveret URL: http://www.forskningsdatabasen.dk/, omfattet indhold: website

Davis, P. M., \& Cohen, S. A. (2001). The effect of the Web on undergraduate citation behavior 1996-1999. Journal of the American Society for information science and technology, 52(4), 309-14.

Dellavalle, R. P., Hester, E. J., Heilig, L. F., Drake, A. L., Kuntzman, J. W., Graber, M., \& Schilling, L. M. (2003). Going, going, gone: Lost Internet references. Science, 302(5646), 787-88.

Den danske kodeks for integritet i forskning. (2014). Uddannelses- og Forskningsministeriet, webarkiv:netarkivet.dk, arkiveringstidspunkt: 2016-02-11 03:02:07 UTC, arkiveret URL: http://ufm.dk/publikationer/2015/ sammenfatning-af-den-danske-kodeks-for-integritet-i-forskning.pdf, omfattet indhold: webdel

Dimitrova, D. V., \& Bugeja, M. (2007). The half-life of internet references cited in communication journals. New Media \& Society, 9(5), 811-26. doi:10.1177/1461444807081226

DISKURS. Lokaliseret på https://diskurs.kb.dk, webarkivreference for forside pwid:archive.org:2016-0811 23.38.27Z:page:https://diskurs.kb.dk/

DISKURS FAQ. Lokaliseret på http://kub.ku.dk/diskurs/faq/, webarkivreference: pwid:archive.org:2017-0127 12.57.50Z:page:http://kub.ku.dk/diskurs/faq

Evans, R. B. (1992). Growing pains: The American Psychological Association from 1903 to 1920. I R. B. Evans, V. S. Sexton, \& T. C. Cadwallader (Red.), The American Psychological Association: A historical perspective, 73-90, Washington, DC: American Psychological Association, xvi.

Forfatterhåndbog. Aarhus Universitetsforlag (2014). Lokaliseret på http://da.unipress.dk/media/2868042/forfatterh ndbog 2014.pdf, webarkivreference:

pwid:archive.org:2015-03-30 05.56.51Z:part:

http://da.unipress.dk/media/2868042/forfatterh ndbog 2014.pdf

Forfattervejledning: Museum Tusculanum. Lokaliseret på

http://www.mtp.hum.ku.dk/rwfolder/mtp/pdfs/forfattervejl.pdf, webarkiv: netarkivet.dk, arkiveringstidspunkt: 2014-06-25 07:31:03 UTC, arkiveret URL:

http://www.mtp.hum.ku.dk/rwfolder/mtp/pdfs/forfattervejl.pdf, omfattet indhold: webdel

Goh, D. H.-L., \& Ng, P. K. (2007). Link Decay in Leading Information Science Journals. Journal of the American Society for Information Science and Technology, 58(1), 15-24. doi:10.1002/asi.20513

Gregersen, M., \& Skiveren, T. (2013). Det åbne redskabsskur: hovedstrømninger i det nye årtusindes danske forfatterskolelitteratur. Aalborg: Aalborg Universitetsforlag.

Haarder, J. H. (2014). Performativ biografisme: en hovedstrømning i det senmodernes skandinaviske litteratur. København: Gyldendal.

Infopid.dk. Lokaliseret på http://infopid.dk/, webarkivreference: pwid:archive.org:2016-1202 09.10.18Z:page:http://infopid.dk/

Isfandyari-Moghaddam, A., \& Saberi, M.-K. (2011). The Life and Death of Urls: The Case of Journal of the Medical Library Association. Library Philosophy and Practice. Lokaliseret på http://digitalcommons.unl.edu/libphilprac/592/, webarkivreference: pwid:archive.org:2017-0127 13.40.13Z:part:http:// 
digitalcommons.unl.edu/cgi/viewcontent.cgi?article=1623\&context=libphilprac

IVA Studenterprojekter. Det Informationsvidenskabelige akademi. Lokaliseret på

http://pure.iva.dk/da/studentthesis/search.html, webarkivreference: pwid:archive.org:2016-03-

06 10.18.19Z:page:http://pure.iva.dk/da/

studentthesis/search.html

Koehler, W. (1999). An Analysis of Web Page and Web Site Constancy and Permanence. Journal of the Association for Information Science and Technology, 50(2), 162-80.

Koehler, W. (2002). Web Page Change and Persistence-a Four-Year Longitudinal Study. Journal of the American Society for Information Science and Technology, 53(2), 162-71.

Kumar, B.T.S. \& Kumar, K.S.M. (2012). Persistence and half-life of URL citations cited in LIS open access journals. Aslib Proceedings, 64(4), 405-22. doi:10.1108/00012531211244752

Larsen, P. S. (2015). Poesiens ekspansion: om nordisk samtidsdigtning. Spring.

Liebler, R., \& Liebert, J. (2012). Something Rotten in the State of Legal Citation: The Life Span of a United States Supreme Court Citation Containing an Internet Link (1996-2010). Yale JL \& Tech., 15, artikel 2.

Mai, A.-M. (2011). Hvor litteraturen finder sted: et bidrag til dansk litteraturs historie. København: Gyldendal.

Mai, A.-M. (2016). Galleri 66: en historie om nyere dansk litteratur. København: Gyldendal.

Moesgaard, J. \& Weimann, S. (2014). De døde links, der blev vakt til live, REVY, 34(2), 3-4.

Mønster, L. (2016). Ny nordisk: lyrik i det 21. århundrede. Aalborg: Aalborg Universitetsforlag.

Nexø, T. A. (2016). Vidnesbyrd fra velfæerdsstaten: den sociale vending i ny dansk litteratur. København: Arena.

Ny forfattervejledning, Samfundslitteratur. Lokaliseret på

http://wildside.ipapercms.dk/SLFonden/SLforlagene/Katalogerflles/Nyforfattervejledning/, webarkivreference: pwid:archive.org:2017-01-27 14.01.45Z:page:

http://wildside.ipapercms.dk/SLFonden/SLforlagene/Katalogerflles/Nyforfattervejledning/

Pope, N. N. (1992). Accuracy of References in Ten Library Science Journals. RQ, 32(2), 240-43.

Preparing and Quoting References using the Harvard System. Lokaliseret på

http://epapers.bham.ac.uk/819/2/B016.1 harvard referencing guide.pdf, webarkivreference:

pwid:archive.org:2017-01-30 09.36.52Z:part:

http://epapers.bham.ac.uk/819/2/B016.1 harvard referencing guide.pdf

Price, A. (2012). Persistent Identifiers in Denmark anno 2012. ScieCom Info, 8(1). Lokaliseret på

http://curis.ku.dk/ws/files/37982162/5428 15494_1 SM.pdf, webarkivreference: pwid:archive.org:2017-01-

27 14.04.53Z:part:

http://curis.ku.dk/ws/files/37982162/5428 154941 _ SM.pdf

Price, D. J. de S. (1963). Little science, big science. New York: Columbia Univ. Press.

Russell, E., \& Kane, J. (2008). The Missing Link: Assessing the Reliability of Internet Citations in History Journals. Technology and Culture, 49(2), 420-29.

Sanderson, R., Phillips, M., \& Van de Sompel, H. (2011). Analyzing the Persistence of Referenced Web 
Resources with Memento. arXiv:1105.3459 [cs]. Lokaliseret på http://arxiv.org/abs/1105.3459, webarkiv: archive.org, arkiveringstidspunkt: 2016-08-06 07:14:30 UTC, arkiveret URL: http://arxiv.org/abs/1105.3459, omfattet indhold: delsite

Serup, M. G. (2013). Relationel poesi. Odense: Syddansk Universitetsforlag.

Skov, A. (2014). Referér korrekt!: Om udarbejdelse af bibliografiske referencer. 2. udgave ved Bo Gerner Nielsen. Det Informationsvidenskabelige Akademi ved Københavns Universitet. Lokaliseret på http://iva.ku.dk/refererkorrekt, webarkivreference: pwid:archive.org:2016-05-15 23.39.48Z:page: http://iva.ku.dk/refererkorrekt

Small, H. (2010). Referencing through history: how the analysis of landmark scholarly texts can inform citation theory. Research Evaluation, 19(3), 185-93. doi:10.3152/095820210X503438

Sompel, H. V. de, \& Davis, S. (2015). From a System of Journals to a Web of Objects. The Serials Librarian, 68(14), 51-63. doi:10.1080/0361526X.2015.1026748

Stidsen, M. (2015). Den ny mimesis. virkelighedstolkningen i dansk og nordisk litteratur efter Anden Verdenskrig, bd. 1 \& 2. U Press, København.

Svendsen, E. (2015). Kampe om virkeligheden: tendenser i dansk prosa 1990-2010. Samfundslitteratur.

Terras, M., Nyhan, J., \& Vanhoutte, E. (2016). Defining Digital Humanities: A Reader. Routledge, New York.

The Chicago Manual of style. (2010) (16. udg.). Chicago: The University of Chicago Press.

Thomee, B., Elizalde, B., Shamma, D. A., Ni, K., Friedland, G., Poland, D., Li, L.-J. (2016). YFCC100M: the new data in multimedia research. Communications of the ACM, 59(2), 64-73. doi:10.1145/2812802

Wren, J. D. (2008). URL decay in MEDLINE - a 4-year follow-up study. Bioinformatics, 24(11), 1381-85. doi:10.1093/bioinformatics/btn127

Zierau, E., Nyvang, C., \& Kromann, T. H. (2016). Persistent Web References - Best Practices and New Suggestions. I Proceedings of the 13th International Conference on Preservation of Digital Objects (iPres), 23746).

Zittrain, J., Kendra, A., \& Lessig, L. (2014). Perma: Scoping and Addressing the Problem of Link and Reference Rot in Legal Citations. Legal Information Management, 14(02), 88-99. doi:10.1017/\$1472669614000255

\footnotetext{
${ }^{1}$ Rækkefølgen er baseret på samtlige fagfællebedømte artikler, der i 2015 blev udgivet inden for det humanistiske felt.

2 Mailkorrespondance med Ulrik Langen (20/9 2016), Tore Tvarnø Lind (20/9 2016), Henrik

Søndergaard (27/9 2016), Anna Vestergaard Jacobsen (26/9 2016), Constanza Navarretta (26/9 2016), Annika Hvithamar (27/9 2016) og Jette Seidelin (28/9 2016).

3 Tallene er fremkommet gennem søgning i Den Danske Forskningsdatabase, der samler publikationsinformationer fra danske forskningsinstitutioner. Ranglisten over danske forlag er baseret på en søgning på dansksprogede monografier publiceret i 2015 af forskere ansat ved danske universiteter. Kun 565 af i alt 612 udgivelser angiver forlaget.

${ }^{4}$ Det samlede antal forsvarede specialer på institutterne udgør 1.059 og fordeler sig på ENGEROM: 117, INSS: 197, TORS: 87, MEF: 256, IKK: 236 og SAXO: 166, jf. artikelforfatternes korrespondance med studiekoordinator Sanne Eyrich (16/1 2017), specialekoordinator Annemarie Hede-Andersen (13/1 2017), studiesekretær Jeanette Sporon-Fiedler (12/1 2017), ledelses- og institutsekretær Birgit Hüttmann (12/1 2017), studiesekretær Nina Simkunas (13/1 2017) og studiesekretær Lis Lachtane (12/1 2017).

${ }^{5}$ Denne database indeholder ikke filer for alle opgaver, og materiale herfra er derfor ikke inddraget i vores unders $\varnothing$ gelse.

${ }^{6}$ Et speciale måtte ekskluderes af undersøgelsen, fordi forfatteren ikke angav specifikke URL'er. Derfor er det ikke muligt
} 
for os at undersøge, om man kan tilgå disse.

7 "Nyere" dækker i denne kontekst perioden fra 2000 og frem, dvs. efter internettets folkelige udbredelse.

${ }^{8}$ Eneste undtagelse er Gregersen og Skiveren (2013), der blev skrevet mens forfatterne endnu var studerende. I videnskabelig approach adskiller værket sig imidlertid ikke fra de øvrige (og forfatterne er i dag ph.d-studerende på hhv. Aalborg Universitet og Aarhus Universitet).

${ }^{9}$ Et værk som f.eks. Soldatens år. Afghanistan-krigen i dansk litteratur og kultur (2014), skrevet af journalisten Klaus Rothstein og udgivet på forlaget Tiderne Skifter, falder ikke uden for rent emnemæssigt (eller nødvendigvis i forhold til dets sprogtone), men på grund af den, utvivlsomt tilsigtede, manglende akademiske akribi.

10 "Persistens" er det nationale og internationale begreb, der anvendes i forskningslitteraturen vedrørende links' levetid.

${ }^{11}$ Eksempler er WebCite (etabl. 1997), archive.is (etabl. i 2012 som archive.today) og perma.cc (etabl. 2013).

${ }^{12}$ Det gælder f.eks. lokalt installeret software såsom DeepVacuum, ArchiveFacebook and Snapz Pro X.

${ }^{13}$ Eksempler er Estlands Eesti Veebiarhiiv, Danmarks Netarkivet, Sveriges Kulturarw3 og Spaniens Archivo de la Web Española.

${ }_{14}$ The Memento Project (http://mementoweb.org/, webarkivreference: pwid:archive.org:2016-11-

03 19.46.56Z:page:http://resaw.eu/about/) giver mulighed for på tværs af åbne webarkiver at undersøge, om en given webside er arkiveret.

${ }^{15}$ Se bl.a. RESAW-netværket, http://resaw.eu/about/, webarkivreference: pwid:archive.org:2016-11-

03 19.46.56Z:page:http://resaw.eu/about/

16 URI (Uniform Resource Identifier) frem for URL (Uniform Resource Locator). 